\title{
The Effects of Legal and Extralegal Factors on Probation Revocation Decisions
}

\author{
P.J. Verrecchia* and Eric Ling
}

York College of Pennsylvania, USA

\begin{abstract}
This study attempts to further the understanding of how legal and extra legal factors affect the decision of criminal justice professionals, specifically, adult probation officers. The findings show that while both legal and extra legal factors were significant in the decision to revoke probation and the length of the sentence, the factors were different for each decision.
\end{abstract}

Keywords: Adult probation, discretion, logistic regression.

In 1964, Piliavin and Briar published their landmark study Police Encounters with Juveniles. In this study, researchers rode with police officers and observed interactions between the officers and juveniles. The juvenile was either wanted by the police (i.e. there was an outstanding warrant for his arrest), a juvenile was present at a call to which an officer was responding, or an officer observed a juvenile engaging in illegal or suspicious behavior (Piliavin and Briar 1964). From their analysis of 66 such encounters, Piliavin and Briar found that police discretion was exercised, but that this discretion was based on not only legal factors (i.e. the seriousness of the suspicious behavior), but also on extralegal factors that included how the juvenile dressed, the juvenile's age and race, and whether the juvenile was cooperative or disrespectful toward the officer (Piliavin and Briar 1964). This study, as well as a "concern over fairness in the criminal justice system" (Freiburger 2011: 143) prompted scholars to examine the influence of extra- legal factors and their effect on the criminal justice process.

Unfortunately there is a paucity of research when it comes to factors affecting the decision-making of probation or parole officers. This is interesting because these criminal justice professionals "have been afforded considerable discretion to individualize offender treatment" (Steiner, Makarios, Travis, III and Meade 2011: 371-372), discretion which has been criticized due to its potential to create disparities in the treatment of different offenders (Burke 1997). It is also interesting because of all of the actors in the criminal justice system, probation/parole officers have the most contact with offenders who are placed under their care. Since the research regarding probation and parole officers is "modest" (Steiner et al. 1991: 373), one must

*Address correspondence to this author at the York College of Pennsylvania, USA; E-mail: pverrecc@ycp.edu look to research conducted on other criminal justice system actors and how legal and extralegal factors influence their decisions.

Researchers have found that legal factors account for most of the variation in the sanctioning decisions of actors in the criminal justice system (Huebner and Bynum 2006; Johnson 2006; Spohn 2000; Spohn and Holleran 2000; Steffensmeier and Demuth 2001; Ulmer and Johnson 2004). For parole officers these legal criteria include severity of violations and prior record. However, just like other decision-makers in the criminal justice system, probation/parole officers' decisions can be influenced by "other factors that may be considered extralegal" (Steiner et al. 2011: 373.).

Empirical research has focused on racial disparities in the American criminal justice system, specifically whether African Americans are sentenced more harshly than White offenders. While researchers have "continually focused" on this area (Mitchell 2005), the results are somewhat inconclusive. Some studies have found that African Americans are sentenced more harshly than Whites, even when controlling for legal factors like prior criminal record and seriousness of the offense (Albonetti 1997; Crawford, Chiricos and Kleck 1998; Kramer and Steffenmesiter 1993). However, other studies found the opposite, that African Americans are sentenced more leniently than Whites (Bernstein, Kelly and Doyle 1977; Myers and Talarico 1996), while some studies have found no differences in sentencing by race (Engen and Gainey 2000). Other studies (Chiricos and Crawford 1995; Kramer and Steffensmerier 1993; Zatz 2000) found that black defendants are more likely to be sentenced to jail or prison than Whites, but that this disadvantage was not found in the length of sentence. The general inconclusiveness of the scientific community to determine whether race plays a role in the criminal 
justice system has led some researchers (Hagan and Bumiller 1983; Mitchell 2005) to address why the body of research diverges on this topic. Indeed, Hagan and Bumiller stated that "The challenge is to explain why some studies find discrimination while others do not" (1983: 31).

Gender of the defendant is an extralegal factor that has received prominent attention in the literature. However, here the findings are more conclusive; women tend to receive sentences that are less harsh than men (Albonetti 1997; Bickle and Peterson 1991; Daly 1989; Spohn and Beichner 2000; Steffensmeier and Demuth 2006; Steffenmesier, Kramer and Streifel 1993; Steffensmeier, Kramer and Ulmer 1995; Steffensmeier, Ulmer and Kramer 1998). Inquiry into the obvious sentencing disparity found evidence that the familial responsibilities of the defendant may have an impact. It has also been suggested that since females have a higher likelihood to care for children, this leniency in sentencing may be based on their greater familial responsibility (Freiburger 2011).

Indeed, research has produced evidence that judges sentence offenders with children more leniently than offenders who do not have children (Bickle and Peterson 1991; Freiburger 2010; Spohn 1999; Spohn and Beichner 2000). Daly (1989) examined the effects of gender and family status using data from Seattle, Washington and New York City. Analysis of the Seattle data revealed that men and women with family ties were less likely to be incarcerated than men and women without family ties. The New York data also showed family ties to be a mitigating factor in sentencing in that women with dependents and women who were married spent less time detained pretrial than women without dependents, and men with dependents were also treated more leniently than men without dependents. However, Daly found that women benefit more from having family ties than men (1989).

Steiner and colleagues found that probation/parole officers make revocation decisions guided by different "focal concerns" (2011: 374); these are the officers' duty to protect the community, the probationer/parolees' blameworthiness, and constraints regarding organizational resources. Assessments of individual blameworthiness are influenced by legal factors, such as severity and sophistication of the offense and prior record. These individuals are seen as a greater risk to reoffend, so a probation/parole officer will impose harsher sanctions on them. However, extralegal factors cannot be ignored as research has demonstrated that offenders who are younger, male, minority and people of color are perceived as a higher risk and a greater threat to the community (Steffensmeier et al. 1998). In addition, probationer/parolees who are employed are less likely to have their probation/parole revoked than those who are unemployed (Spohn and Holleran 2000).

\section{METHODS}

The purpose of this study is to determine the effect of legal and extralegal factors on probation/parole officer's decisions in the revocation of their clients' probation or parole. Data were collected from an adult probation/parole department in South Central Pennsylvania on 353 adults who were on probation or parole and had that probation/parole revoked due to committing a new offense (not for committing a technical violation). However, due to missing data in some cases our final sample size was 193 cases.

\section{Legal Independent Variables}

One legal factor that influences the decision making of probationlparole offices is the severity of the new offense. We are using the Offense Gravity Score (OGS) of the new offense, which we dichotomized as 0 (OGS of 1-4) and 1 (OGS of 5-8). In our sample, 149 $(77.1 \%)$ offenders committed a new offense with an OGS between 1 and 4 (less serious offenses) while 44 (22.9\%) offenders committed a new offense with an OGS between 5 and 8 (more serious offenses).

Another legal factor that was examined was whether the probationer/parolee tested positive for drug or alcohol use (coded as 0 for no and 1 for yes) while under supervision. Of our sample, $38(19.7 \%)$ tested positive for alcohol use while $155(80.3 \%)$ did not, and $89(46.1 \%)$ tested positive for drug use while 104 (53.9\%) did not. The last two legal factors that we examined were prior offense (coded as 0 for no and 1 for yes ${ }^{1}$ ) and prior incarceration (coded as 0 for no and 1 for yes). In our sample, 111 (57.6\%) offenders were under supervision for their first offense while 82 $(42.4 \%)$ offenders were under supervision for their second offense. Twenty-one (10.9\%) offenders had been incarcerated previously while 172 (89.1\%) had not.

\footnotetext{
${ }^{1}$ To control for number of prior offenses we only included offenders who had committed one prior offense or who were under supervision for their first offense.
} 
Table 1: Codes and Frequencies for Independent and Dependent Variables ( $N=193)$

\begin{tabular}{|c|c|c|}
\hline Variable (coding) & Frequency & Percent \\
\hline \multicolumn{3}{|l|}{ Independent Variable } \\
\hline \multicolumn{3}{|l|}{ OGS } \\
\hline $1-4(0)$ & 149 & 77.2 \\
\hline $5-8(1)$ & 44 & 22.8 \\
\hline \multicolumn{3}{|l|}{ Gender } \\
\hline Male (0) & 146 & 75.4 \\
\hline Female (1) & 47 & 24.6 \\
\hline \multicolumn{3}{|l|}{ Drug Use } \\
\hline No (0) & 104 & 53.9 \\
\hline Yes (1) & 89 & 46.1 \\
\hline \multicolumn{3}{|l|}{ Alcohol Use } \\
\hline No (0) & 155 & 80.3 \\
\hline Yes (1) & 38 & 19.7 \\
\hline \multicolumn{3}{|l|}{ Incarceration } \\
\hline No (0) & 172 & 89.1 \\
\hline Yes (1) & 21 & 10.9 \\
\hline \multicolumn{3}{|l|}{ Prior Offense } \\
\hline No $(0)$ & 111 & 57.6 \\
\hline Yes (1) & 82 & 42.4 \\
\hline \multicolumn{3}{|l|}{ Race } \\
\hline White (0) & 125 & 71.3 \\
\hline Non-White (1) & 68 & 26.1 \\
\hline \multicolumn{3}{|l|}{ Employment } \\
\hline Unemployed (0) & 115 & 59.5 \\
\hline Employed or in School (1) & 78 & 40.5 \\
\hline \multicolumn{3}{|l|}{ Education } \\
\hline High School Dropout (1) & 61 & 31.8 \\
\hline GED or High School (2) & 132 & 68.2 \\
\hline \multicolumn{3}{|l|}{ Status } \\
\hline Unmarried (0) & 170 & 88.1 \\
\hline Married (1) & 23 & 11.9 \\
\hline \multicolumn{3}{|l|}{ Priors } \\
\hline No $(0)$ & 111 & 57.6 \\
\hline Yes (1) & 82 & 42.4 \\
\hline \multicolumn{3}{|l|}{ Dependent Variables } \\
\hline \multicolumn{3}{|l|}{ Sentence } \\
\hline Probation (0) & 98 & 51.0 \\
\hline Incarceration (1) & 95 & 49.0 \\
\hline \multicolumn{3}{|l|}{ Sentence Length (months) } \\
\hline 9 months or less $(0)$ & 100 & 51.8 \\
\hline 10 months or more (1) & 93 & 48.2 \\
\hline
\end{tabular}

\section{Extralegal Independent Variables}

We coded gender as 0 for male and 1 for female. Of the sample members, 146 (75.4\%) were male and 77 $(24.6 \%)$ were female. Race was coded as 0 for White and 1 for non-White. Our sample comprised 125 $(71.3 \%)$ White offenders and 68 (28.7\%) non-White offenders. A third extralegal independent variable was employment status which was dichotomized as 0 for 
unemployed and 1 for employed or in school. In our sample, $115(59.5 \%)$ offenders were unemployed and $78(34.8 \%)$ were employed or in school. Education was coded as 0 for no high school diploma or GED and 1 for high school graduate or GED. Sixty-one (31.8\%) offenders had no high school education or GED while $132(68.2 \%)$ did have at least a high school diploma or GED. The last extralegal independent variable we examined was marital status which was coded as 0 for unmarried and 1 as married. Of our sample members, $170(88.1 \%)$ offenders were unmarried and $23(11.9 \%)$ were married.

\section{Dependent Variables}

In examining the revocation decisions of probation/parole officers we examined two things. One, whether the revocation would include the probationer/parole remaining on probation (which, presumably, would include more stringent conditions) or whether the offender would be incarcerated. The second dependent variable was the length of the sentence imposed (for either continued probation or incarceration). Sentence was coded as 0 for continued probation/parole and length of sentence was coded as 0 for nine months or less and 1 for 10 months or more. In our sample, $98(51 \%)$ offenders were sentenced to continued probation/parole while 95 (49\%) were sentenced to incarceration. One hundred (51.8\%) received a sentence length of 9 months or less while $93(48.2 \%)$ received a sentence length of 10 months or more.

\section{RESULTS}

Logistic regression models were used to assess the effects of the independent variables on sentence (continued probation or incarceration) first. In the first model one legal and two extralegal factors were significant. Offenders who had been previously incarcerated $(b=1.967)$ and committed a new offense under supervision had a $600 \%$ increased odds of being incarcerated compared to offenders who violated and had not been previously incarcerated. However, that was the only legal factor that was significant in the model.

Interestingly, two extralegal factors had a significant impact on probation/parole officers' decision making. Men $(b=-1.029)$ had a $64 \%$ increased odds of being incarcerated to compared to women, and the unemployed $(b=-.971)$ had increased odds of $164 \%$ of being incarcerated compared to offenders under supervision who were employed or in school.

In the second model with length of sentence as the dependent variable there were two independent

Table 2: Logistic Regression Results for Effect on Sentence

\begin{tabular}{|c|c|c|c|c|c|}
\hline Variable & b & S.E. & Wald & Sig. & $\operatorname{Exp}(b)$ \\
\hline OGS & .124 & .112 & 1.223 & .269 & 1.132 \\
\hline Gender** & -1.029 & .386 & 7.105 & .008 & .357 \\
\hline Drug Use ${ }^{A}$ & -.689 & .361 & 3.636 & .057 & .502 \\
\hline Alcohol Use & -.507 & .454 & 1.246 & .264 & .603 \\
\hline Incarceration ${ }^{* *}$ & 1.967 & .634 & 9.617 & .002 & 7.151 \\
\hline Race & .441 & .355 & 1.542 & .241 & 1.554 \\
\hline Employment ${ }^{\star *}$ & .971 & .354 & 7.526 & .006 & 2.640 \\
\hline Education $^{\mathrm{A}}$ & -.637 & .347 & 3.359 & .067 & .529 \\
\hline Status & -.272 & .518 & .276 & .600 & .762 \\
\hline Priors & -.401 & .359 & 1.247 & .264 & .670 \\
\hline Constant & -.021 & 1.412 & .000 & .988 & .979 \\
\hline -2 Log-likelihood & 230.145 & & & & \\
\hline Model chi-square & $37.280^{\star \star * *}$ & & & & \\
\hline Cox and Snell $\mathrm{R}^{2}$ & .176 & & & & \\
\hline Nagelkerke $R^{2}$ & .234 & & & & \\
\hline
\end{tabular}

Note: ${ }^{* \star} p<.01,{ }^{* * \star} p<.001, A p<.10$. 
Table 3: Logistic Regression Results for Effect on Length

\begin{tabular}{|c|c|c|c|c|c|}
\hline Variable & b & S.E. & Wald & Sig. & $\operatorname{Exp}(b)$ \\
\hline OGS & -.360 & .392 & .844 & .358 & .698 \\
\hline Gender $^{A}$ & .685 & .361 & 3.604 & .058 & 1.984 \\
\hline Drug Use $e^{\star *}$ & .840 & .320 & 6.885 & .009 & 2.315 \\
\hline Alcohol Use ${ }^{A}$ & -.758 & .425 & 3.180 & .075 & .469 \\
\hline Incarceration & -.496 & .529 & .881 & .348 & .609 \\
\hline Race & -.129 & .344 & .140 & .708 & .879 \\
\hline Employment* & -.826 & .342 & 5.828 & .016 & .438 \\
\hline Education $^{A}$ & .635 & .340 & 3.490 & .062 & 1.888 \\
\hline Status & -.464 & .516 & .810 & .368 & .629 \\
\hline Priors $^{A}$ & -.594 & .351 & 2.858 & .091 & 1.811 \\
\hline Constant & -.243 & .619 & .154 & .695 & .785 \\
\hline -2 Log-likelihood & 242.605 & & & & \\
\hline Model chi-square & $24.696^{* *}$ & & & & \\
\hline Cox and Snell $R^{2}$ & .120 & & & & \\
\hline Nagelkerke $R^{2}$ & .160 & & & & \\
\hline
\end{tabular}

Note: ${ }^{*} \mathrm{p}<.05,{ }^{* *} \mathrm{p}<.01,{ }^{* * *} \mathrm{p}<.001, \mathrm{~A} \mathrm{p}<.10$.

variables that were significant, one legal and one extralegal. Offenders who tested positive for drug use while under supervision $(b=.840)$ had an increased odds of $130 \%$ of receiving a longer sentence than those who did not test positive. The extralegal variable employment $(b=-.826)$ was once again significant, as the unemployed had $56 \%$ increased odds of receiving a longer sentence than probation/parole violators who were employed or in school.

\section{DISCUSSION}

Just as severity of offense determines length of the initial sentence, similarly, severity of new offense has obvious effects on the decision to revoke an offender's parole or probation. Interestingly, for the majority $(77.1 \%)$ of the parolees and probationers in our sample, the severity of the new offense was in fact at the lower end of the offending severity scale. For our sample, the legal factor that predicted revocation most clearly was previous incarceration. It may be that probation officers are reluctant to commit probationers to a period of incarceration when they have not served time before. The officers of our probationers and parolees were prepared to send the previously incarcerated back to serve further time. Although beyond the scope of the present study, the logic of such a decision may well be based on a belief that such offenders are hardened and deserve further harsh punishment. If this is so, this belief would go some way in explaining the extralegal factors that influence decisions to revoke or impose increased sanctions on offenders.

In terms of extralegal factors, research on officers' understandings could shed light on various dimensions of decision-making. It is possible that officers hold traditional understandings and beliefs concerning gender roles. Males in our sample were much more likely to face incarceration than females. Parole/probation officers were also hard on the unemployed. If officers hold to a traditional mindset, they may see the unemployed as undeserving and this might explain the far greater odds of being incarcerated if a probationer/parolee is unemployed. The reasoning seems to be that those who deserve a break are offenders who are employed or in school.

The data from the study support several conclusions regarding the decision of parole/probation officers to revoke parole or probation of offenders committing new offenses. While there is variation between parole/probation officers in their responses to 
an individual offender's positive test for drug or alcohol use, the aggregate data confirm that a positive test is more likely to lead to revocation.

The findings suggest that probation/parole officers consider extralegal as well as legal factors when revoking a client's probation/parole. While each of the probationers/parolees in the sample committed a new offense which started the revocation process, probation/parole officers exercise their discretion in how to handle the violation. In the sample offenders either remained on probation or were sentenced to a period of incarceration. Further research should be conducted on parole/probation officers' use of both traditional understandings of gender roles and simple beliefs concerning the deserving or undeserving offender.

Future research in this area should address the limitations of this study. We were limited to official data from one county so it is questionable whether our results can be generalized to other populations. Also, the sample size for females is relatively small. It also would be beneficial to explore the effect of familial variables on the effect of probation/parole officer decision making.

\section{REFERENCES}

Albonetti, C. 1997. "Sentencing Under the Federal Sentencing Guidelines: Effects of Defendant Characteristics, Guilty Pleas, and Departures on Sentencing Outcomes for Drug Offenses, 1991-1992." Law and Society Review 31(4): 789822.

http://dx.doi.org/10.2307/3053987

Bernstein, I.N., Kelly, W.R. \& Doyle, P.A. 1977. "Societal Reactions to Deviants: The Case of Criminal Defendants." American Sociological Review, 42: 743-755 http://dx.doi.org/10.2307/2094863

Bickle, G.S. \& Peterson, R.D. 1991. "The Impact of Gender-Based Family Roles on Criminal Sentencing." Social Problems, 38(3): 372-394.

http://dx.doi.org/10.2307/800605

Burke, P. 1997. Policy-Driven Responses to Probation and Parole Violations. Silver Spring, MD: Center for Effective Public Policy.

Chiricos, T.G. \& Crawford, C. 1995. "Race and Imprisonment: A Contextual Assessment of the Evidence." In Hawkins, D.F. (ed.) Ethnicity, Race and Crime: Perspectives Across Time and Place. State University of New York Press: Albany, NY: 281-309.

Daly, K. 1989. "Neither Conflict for Labeling nor Paternalism Will Suffice: Intersections of Race, Ethnicity, Gender, and Family in Criminal Court Decisions." Crime and Delinquency, 35: 136-168. http://dx.doi.org/10.1177/0011128789035001007

Engen, R.L. \& Gainey, R.R. 2000. "Modeling the Effects of Legally Relevant and Extralegal Factors Under Sentencing Guidelines: The Rules have Changed." Criminology, 38: 1207-1225.

http://dx.doi.org/10.1111/j.1745-9125.2000.tb01419.x
Freiburger, T.L. 2010. "The Effects of Gender, Family Status, and Race on Sentencing Decisions." Sciences and the Law, 24: 378-395.

Freiburger, T.L. 2011. "The Impact of Gender, Offense Type, and Familial Role on the Decision to Incarcerate." Social Justice Research, 24: 143-167. http://dx.doi.org/10.1007/s11211-011-0133-8

Hagan, J. \& Bumiller, K. 1983. "Making Sense of Sentencing: A Review and Critique of Sentencing Research." In Blumstein, A., Cohen, J., Martin, S.E. \& Tonry, M.H. (eds.), Research on Sentencing: The Search for Reform, Vol.2, National Academy Press: Washington, DC: 1-54

Huebner, B.M. \& Bynum, T.S. 2006. "An Analysis of Parole Decision Making Using a Sample of Sex Offenders: A Focal Concerns Perspective." Criminology, 44: 961-991. http://dx.doi.org/10.1111/j.1745-9125.2006.00069.x

Johnson, B. 2006. "The Multilevel Context of Criminal Sentencing: Integrating Judge-and County Level Influences." Criminology, 44: 259-298.

http://dx.doi.org/10.1111/j.1745-9125.2006.00049.x

Kramer, J. \& Steffensmeier, D. 1993. "Race and Imprisonment Decisions." Sociological Quarterly, 34: 357-376. http://dx.doi.org/10.1111/j.1533-8525.1993.tb00395.x

Mitchell, O. 2005. "A Meta-Analysis of Race and Sentencing Research: Explaining the Inconsistencies." Journal of Quantitative Criminology, 21(4): 439-466. http://dx.doi.org/10.1007/s10940-005-7362-7

Myers, M.A. \& Talarico, S.M. 1986. "The Social Contexts of Racia Discrimination in Sentencing." Social Problems, 33: 236-251. http://dx.doi.org/10.2307/800707

Piliavin, I. \& Briar, S. 1964. "Police Encounters with Juveniles." American Journal of Sociology, 70: 206-214. http://dx.doi.org/10.1086/223794

Spohn, C. 1999. "Gender and Sentencing of Drug Offenders: Is Chivalry Dead?" Criminal Justice Policy Review, 9(3): 365399.

Spohn, C. 2000. "Thirty Years of Sentencing Reform: The Quest for a Racially Neutral Sentencing Process." In National Institute of Justice (ed.), Policies, Processes and Decisions of the Criminal Justice System: Criminal Justice 2000, Vol.3. Washington, DC: National Institute of Justice.

Spohn, C. \& Beichner, D. 2000. "Is Preferential Treatment of Felony Offenders a Thing of the Past? A Multisite Study of Gender, Race and Imprisonment." Criminal Justice Policy Review, 11(2): 149-184

Spohn, C. \& Holleran, D. 2000. "The Imprisonment Penalty Paid by Younger, Unemployed Black and Hispanic Male Offenders." Criminology, 38: 281-306. http://dx.doi.org/10.1111/j.1745-9125.2000.tb00891.x

Steffensmeier, D. \& Demuth, S. 2001. "Ethnicity and Judges Sentencing Decisions: Hispanic Black-White Comparisons." Criminology, 39: 145-178. http://dx.doi.org/10.1111/j.1745-9125.2001.tb00919.x

Steffensmeier, D. \& Demuth, S. 2006. "Does Gender Modify the Effects of Race-Ethnicity Criminal Sentence? Sentences for Male and Female White, Black and Hispanic Defendants." Journal of Quantitative Criminology, 22: 241-261. http://dx.doi.org/10.1007/s10940-006-9010-2

Steffensmeier, D., Kramer, J. \& Streifel, C. 1993. "Gender and Imprisonment Decisions." Criminology, 31(3): 411-446. http://dx.doi.org/10.1111/j.1745-9125.1993.tb01136.x

Steffensmeier, D., Kramer, J. \& Ulmer, J. 1995. "Age Differences in Sentencing." Justice Quarterly, 12: 583-602. http://dx.doi.org/10.1080/07418829500096151

Steffensmeier, D., Ulmer, J. \& Kramer, J. 1998. "The Interaction of Race, Gender and Age in Criminal Sentencing: The Punishment Cost of Being Young, Black and Male." Criminology, 36(4): 763-797. http://dx.doi.org/10.1111/j.1745-9125.1998.tb01265.x 
Steiner, B., Makarios, M.D., Travis, III, L.F. \& Meade, B. 2011. "Short-Term Effects of Sanctioning Reform on Parole Officers' Revocation Decisions." Law and Society Review, 42(2): 371-400.

http://dx.doi.org/10.1111/j.1540-5893.2011.00440.x

Ulmer, J. \& Johnson, B. 2004. "Sentencing in Context: A Multilevel Analysis." Criminology, 42: 197-177.

http://dx.doi.org/10.1111/j.1745-9125.2004.tb00516.x
Zatz, M.S. 2000. "The Convergence of Race, Ethnicity, Gender and Class on Decision Making: Looking Toward the $21^{\text {st }}$ Century." In Horney, J. (ed.) Criminal Justice 2000, Vol. 3: Policies, Processes and Decisions of the Justice System. Department of Justice: Washington, DC.

Received on 14-02-2013

Accepted on 20-03-2013

Published on 27-03-2013

DOI: http://dx.doi.org/10.6000/1929-4409.2013.02.3

(C) 2013 Verrecchia and Ling; Licensee Lifescience Global.

This is an open access article licensed under the terms of the Creative Commons Attribution Non-Commercial License (http://creativecommons.org/licenses/by-nc/3.0/) which permits unrestricted, non-commercial use, distribution and reproduction in any medium, provided the work is properly cited. 